\title{
The production of contraceptive cyborgs in Swedish upper secondary sexuality education
}

\author{
Sara Planting-Bergloo ${ }^{1}$ (D) A. A. Orlander ${ }^{1} \cdot$ B. Jakobson ${ }^{1}$
}

Received: 14 February 2021 / Accepted: 20 September 2021 / Published online: 16 December 2021

(c) The Author(s) 2021

\begin{abstract}
In this study we examine upper secondary students' notions of contraceptive methods, as human reproduction and contraception are common content in sexuality education in Sweden and worldwide. Our data were constructed during an extensive educational sequence in natural science sexuality education and include audio recordings of 17-18-year-old students' stories. Since the main body of the stories was about hormonal and digital contraception and contraceptive responsibility, these stories are the focal point of our analysis. Our study further aims to problematize, challenge, and develop education on contraceptive methods, and Donna Haraway's theoretical perspectives have been particularly useful. We have in the analytical process linked Haraway's cyborg image with her later work on tentacular thinking. Our result shows that scientific facts about human reproduction are important for the students' ability to navigate between the advantages and disadvantages of various contraceptive methods. However, sexuality education turns out to not only be a matter of scientific facts. This study accentuates how natural science, historical, political, cultural, and market-oriented intertwinings affect students' notions of contraception-and thereby also the construction of natural science sexuality education.
\end{abstract}

Keywords Sexuality education · Contraceptive methods · Upper secondary school $\cdot$ Donna Haraway

Several overviews, such as that of Evert Ketting and Olena Ivanova (2018) of sexuality education in 25 European and Central Asian countries, have stated that human reproduction and contraception are common teaching content worldwide. In parallel, the field of critical sexuality education studies has mainly focused on identifying dominant discourses and power structures within educational settings and has problematized what counts as sexuality education (Allen and Rasmussen 2017). Anna Bredström, Eva Bolander, and Jenny Bengtsson (2018) have moreover noted that the Swedish sexuality education research has mainly been concerned with the school's core values and general work on norms, gender, and equality. Classroom-based studies on the construction of sexuality education are rare (Ketting and Ivanova 2018).

Sara Planting-Bergloo

sara.planting.bergloo@mnd.su.se

1 Department of Mathematics and Science Education, Stockholm University, Stockholm, Sweden 
According to a survey among 16-29-year-old Swedish adolescents the school provide adequate knowledge of condom usage, the body, and how to get pregnant (Public Health Agency of Sweden 2017). In this study reproductive and contraceptive content is also evident in the participating teacher's lectures on sexually transmitted infections, hormones involved in ovulation and sperm production, and in the students' own exploration of contraceptive methods. The upper secondary teacher and students are, however, actively linking the Swedish natural science sexuality education to a broader societal context. With a grounding in Donna Haraway's (1991) writings on the cyborg, we use the student conversations to delineate the last century's transformation of the human body into contraceptive cyborgs.

In the following section, we provide a brief description of the educational setting which frames the study.

\section{A story about contemporary Swedish upper secondary sexuality education}

It was late spring and the 17-18-year-old students were about to finish their second upper secondary school year. The class had, over the preceding year, taken the compulsory course science studies-analogous to natural science subjects for students not attending a natural science upper secondary program. As the lesson started, the 25 students were slowly gathering on the cold but sunny school ground. Feelings of expectation hovered in the air as the students were well aware of the academic content of the educational episode aheadsexuality education. The lesson began and the teacher briefly introduced the first author, also an upper secondary biology teacher, before leading the class to view a nearby outdoor work of art. The artwork, which concerned sexuality and genitals, introduced the upcoming educational unit to the students. It was also used as the basis for student discussions on gender in the following class and exemplifies the creative teaching style of the teacher. The weeks that followed included lectures on Swedish sexuality education history, hormonal regulation of sperm and ovarian follicle production, and a simulation of the potential spread of sexually transmitted infections (STIs) as well as a student-centered assignment on norms. Gender neutral pronouns and words, such as "uterus-carrier," "prostate-carrier," "sexual practice," and "sexual partner," were systematically used by the teacher who was committed to identifying and challenging norms within sexuality education. The participating students' were often already familiar to the vocabulary as several of the school's teachers practiced a critique of norms, as proposed in Swedish regulatory guidelines. Many of the school's students were also actively engaged in feminist and LGBTQ (lesbian, gay, bisexual, trans, and queer) issues and had, just before the study was conducted, organized a pride week at the school. The teacher's use of, for example, gender neutral pronouns was an attempt to create norm awareness. It could, however, also be interpreted as an act of language activism (Årman 2020). Language activism is explained later in this section.

As the teaching unit progressed, the students were individually assigned tasks to explore natural and social science aspects of a norm related to sexuality-an interpretation of the syllabi in science studies (Swedish National Agency for Education 2012). The students were encouraged to choose norms based on their own interests, so their work focused on topics such as porn, plastic surgery, menstruation, contraception, and virginity. They also tried to complicate their work by, for example, using gender neutral words. However, as most of the student assignments concerned the male-female dichotomy and 
heteronormativity in relation to sexuality, words such as "women," "men," "femininity," and "masculinity" were also used in class. The student assignment took several weeks of science lessons to accomplish. The students read and wrote individually but often paired or grouped themselves to discuss their own or other's texts. At the end of the teaching unit, the teacher arranged a formal peer reading prior to the oral examination.

To further explain the context of the study, we turn to the work of the scholar Henning Årman (2020) as well as the first author's own experiences from research and from ten years of teaching in a similar school context. In Sweden, some upper secondary schools attract students interested in societal challenges, such as anti-racist, queer, and feminist issues. In these, mostly urban contexts, the everyday language use of for example gender neutral pronouns and words is considered an important tool for achieving social transformation and inclusion. Students and teachers practicing language activism are, however, not generic to the Swedish school system and far from all students in the school of the study participated in the language transformation processes. Consequently, these specific school contexts can be looked upon as a condensation of similar on-going processes in the society (Årman 2020).

During the whole teaching unit, which included 12 lessons over six weeks, the first author was present in class, taking notes, and audio recording approximately $13 \mathrm{~h}$ of lectures and student talks. The audio-recorded data were transcribed in full in the subsequent analytical process and sorted according to the students' talking points. Due to its linkages to the preventive approach in sexuality education, in Sweden and internationally (Ketting \& Ivanova 2018; Public Health Agency of Sweden 2017), student conversations on contraceptive methods were chosen for further analysis. As the main body of the conversations concerned hormonal and digital contraceptives, and the responsibility for protection, these are the focal point of the analysis. Hormonal contraceptives have been on the market for more than fifty years. Digital contraceptives are, however, quite a new phenomenon. The digital contraceptive methods described in this study are smartphone applications using algorithms and daily temperature measurements to calculate the fertility window.

\section{The history of Swedish sexuality education}

Swedish sexuality education, focusing on health, cleanliness, and ethics, began in the latter part of the 1800s (Hultén 2008). In 1955, it became compulsory and has since maintained its status in Sweden as a tool "for fostering a healthy development among the Swedish population and particularly the Swedish youth" (Bredström, Bolander and Bengtsson, 2018, p. 539-540) and internationally (Ringrose, Whitehead, Regehr and Jenkinson, 2019). In Sweden in the 1970s, the idea of abstinence until marriage was abandoned in sexuality education and replaced with the notion of sexual responsibility-mainly through education on contraceptive methods (Bolander, 2015; Sandström, 2001). The approach was later transformed into a pleasure-oriented sex education (Bäckman, 2003), a grounding which is still practiced in Swedish schools.

In recent years, an education aiming for a critique of norms has been adopted by teachers and policy makers (Langmann and Månsson, 2016) and is, for example, salient in contemporary regulatory guidelines for sexuality education (Swedish National Agency for Education 2013a,b, 2014). The norm-critical approach, influenced by the anti-oppressive education suggested by Kevin Kumashiro (2000), created a venue for the educational episode framing this study. To further exemplify the norm-critical and sex-positive outset in Swedish sexuality education we turn to the animated film Sex on the Map (Dahlöf, 2011), 
produced by the Swedish Educational Broadcasting Company and The Swedish Association for Sexuality Education. The film is addressing the most frequently asked questions from 13- to 16-year-old Swedish students (Bredström, Bolander and Bengtsson 2018; Ollis 2016). Even though the film aims at creating norm awareness and is addressing plurality, it has turned out to emphasize a sex-positive and pleasure-oriented sexuality as more ideal than others (Bredström, Bolander and Bengtsson 2018). Closer examination of a normcritical pedagogy is, however, beyond the scope of this paper.

In the following section, we discuss the theoretical perspective used in our analysis of the student conversations on contraceptive methods.

\section{Theoretical perspective: the human transformation to contraceptive cyborgs}

This study takes its theoretical departure from Donna Haraway's (1991) cyborg image, where a cyborg is most simply described as a hybrid of organism and machine, consisting of both biological tissue and synthetic or digital parts. The cyborg thereby works as a tool to blur the boundaries of dualism, such as nature-culture, body-mind, natural-technical, and organism-machine.

The cyborg image also concerns Western biopolitics (Haraway 1991). Biopolitics or biopower are concepts mainly associated with the work of Michel Foucault (1980, 2008, 2010) and describe how the body, since the beginning of the 1600s, has been one of the main concerns for Western political and governmental exercise of power. Biopolitical thought is, however, not a new idea and can be traced back to ancient Greece. Aristotle and Plato were, much like researchers in the mid-1900s, concerned with population growth and in particular increased numbers of the poor (Ojankangas 2017). In the 1950s, the contraceptive pill was introduced for the same reasons. It did, however, also present sexual independence as well as liberation from continual child births for many women (Marks 2001).

Since the 1970s, biopolitical theorizing has concerned not only the biological body, but also the blurring of boundaries between "natural" and "artificial" forms of life (Lemke 2011). Haraway (1991) describes this as techno-biopolitics. Through the cyborg image and examples from the field of immunology, she problematizes organism boundaries by showing how, over the past century, historical, hierarchical, and localized bodies have gradually transformed into cybernetic communication systems. Accordingly, communication and biotechnologies are tools for recrafting the body, turning humans into cyborg fictions. The transformation and control, which applies especially to the female body (Haraway 1991), also take place in the analytical part of this study — where the historical transform of the body into gendered contraceptive cyborgs is displayed.

In summary, modern medicine, such as contraceptive research, has for the past hundred years made contraceptive methods an apparatus for bodily production. The cyborg image and the concept of techno-biopolitics have therefore proved fruitful analytical tools for our sexuality education work on contraceptive methods.

\section{Methodology: tentacular thinking}

In this study, the cyborg image (Haraway 1991) - the contraceptives-controlled human body - is linked to Haraway's later (2016) work on tentacular thinking. Accordingly, the contraceptive cyborg will be imagined as a tentacular creature, with a myriad of tentacles telling the story of contraception, offering a more entangled, less binary life story. The 
tentacular contraceptive cyborg can also be seen as a sort of IT creature, with nets and networks blurring digital and biological boundaries.

We use tentacular thinking because tentacular creatures hold the ability to "make attachments and detachments; they ake cuts and knots; they make a difference; they weave paths and consequences but not determinisms; they are both open and knotted in some ways and not others" (Haraway 2016, p. 31). Tentacular thinking can be compared to diffractive reading. According to scholars such as Hillevi Lenz Taguchi (2012), Lisa Mazzei (2014), and Bronwyn Davies (2014), a diffractive reading leads us in different directions and keeps the analysis and knowledge on the move. It further relies on our ability as researchers to consider the entanglement of bodies, texts, data, language, and theory within the analytic process. To do so, this study uses student stories about contraceptive methods to make broad associations with natural science, historical, cultural, political, and market-oriented contraceptive intertwinings.

In summary, this study uses the cyborg image and tentacular thinking in the process of "threading, felting, tangling, tracking, and sorting" (Haraway 2016, p. 31) the student stories on contraceptive methods. In the analysis, we follow the cyborgs and their tentacles as they emerge and unfold in the student stories, but we also link the tentacles in the final analysis. The linking of tentacles foreground and background different outcomes in the concluding discussion.

The main purpose of this study is to explore Swedish upper secondary students' notions of contraceptives. With a grounding in the cyborg image this study holds the opportunity to both problematize and open up for new perspectives in education on contraceptive methods. The question guiding this study is: How can students' notions of contraceptives challenge, problematize, and develop the construction of Swedish natural science sexuality education?

\section{Response-ability}

Haraway (2016) stresses the need to cultivate "response-ability" in the collective process of knowing and doing. Accordingly, this study relates to response-ability in several ways:

Tentacular thinking holds the possibility of more entangled life stories. The enactment of various tentacles is, however, crucial for what comes to matter in the study. Put in Haraway's (2016, p.13) wording "who is/are to be in/of the world is constituted in intra- and interaction." We therefore acknowledge that the researchers are part of the construction of the tentacles and in the choice of student conversations to represent them.

The knotted patterns and possibilities of the student stories also come with care and a response-ability to stay with the trouble. Caring is in this study interpreted as the courage to stay with the concerns raised by the participating students. In order to do so we have chosen to explore other contraceptive patterns than the Swedish mainstream education on condom use and the prevention of STIs (Bolander 2015).

As researchers should also note to whom one is responsible (Haraway 2016), our obligations toward the participants have been under consideration. Due to the teacher's normcritical stance and specific request we do not put the results in relation to, for example, sexual identity, class, or ethnicity. All the students are therefore neutrally named "S." The neutral naming of students is besides its relating to the Swedish norm-critical context also connected to the theoretical perspectives of this study. The cyborg is a post-gendered creature (Haraway 1991). 
Response-ability is related to general ethical and data protection regulations. The class of 25 students was informed about the study verbally and in writing (two declined to participate). The participating students were also verbally repeatedly asked about their willingness to participate in the ongoing audio recordings. The European General Data Protection Regulation, GDPR (EU 2016/679, 2016), has declared certain data to be particularly sensitive. Since this study concerns upper secondary sexuality education and our data may include personal information on sexuality, it has required approval from the Swedish Ethical Review Board.

Response-ability is further understood within the perspective of digital media ethics. Since our data concern not only the classroom context but also students' lived experiences of digital media, we have been inspired generally by digital media ethnography and specifically by Internet research: Ethical Guidelines 3.0 (franzke, Bechmann, Zimmer, Ess and the Association of Internet Researchers 2020). The guidelines advocate a context-based, procedural, and ongoing ethics in relation to the digital media content in the students' stories. The influencers in the student stories therefore remain anonymous, and the digital contraceptive methods mentioned are not named.

\section{Student's stories on contraceptive methods}

Before we introduce the student's stories we provide an overview of European and Swedish teenage use of contraceptive methods. Condoms are used by on average two-thirds of European 15-year-olds - indicating that condoms are both affordable and available for teenagers. Use of oral and hormonal contraceptive methods showed, however, much more variation across Europe. On average, just over a quarter of the 15-year-olds or their partners had used hormonal contraceptives. In Sweden $54 \%$ of the sexually active 15 -year-olds had used condoms and $32 \%$ of them (or their partners) had at some point used hormonal contraceptives (Ketting and Ivanova, 2018). To summarize, the use of hormonal contraceptives was somewhat more widespread in Sweden compared to the rest of Europe.

To exemplify the preventive Swedish sexuality education we turn to the lower and upper secondary syllabi in Biology (Swedish National Agency for Education 2013a, 2013b). The core content for the school subject includes topics such as puberty, love, responsibility, and gender equality, but it also addresses the prevention of STIs and unwanted pregnancy. However, since the 1970s the Swedish sexuality education no longer promotes preventive methods, such as coitus interruptus, safe periods, and abstinence-until-marriage. Instead, it advocates condom use for preventing the spread of STIs (Bolander, 2015) and various contraceptive methods for preventing unwanted pregnancy. Although the preventive perspective is not as explicit in the subject of science studies, the school subject framing this study, contraceptive methods were still addressed. Possibly a result of the participating biology teacher's own background, experience and choice and the preventive and reproductive tradition enclosing natural science sexuality education. As this study mainly concerns the use of hormonal and digital contraceptives, our use of the word "contraceptive method" refers to methods preventing unwanted pregnancy and not the transmission of STIs.

According to a recent review carried out by the Swedish Schools Inspectorate (2018), students are rarely involved in discussions about sexuality education and their own concerns might therefore not be addressed. Louise Allen (2005) has come to the same conclusion in the New Zealand context. However, the teacher participating in this study was committed to include the students' own perspectives in teaching. The students were therefore assigned to explore natural and social science aspects of norms related to sexuality. The 
topic of exploration was their own choice. Several of the 17-18-year-old students in our study were interested in norms concerning contraceptive methods, but for different reasons. A common denominator, however, was that the students were concerned about contraceptive methods aimed at uterus-carriers; condoms were not of the same interest.

In the initial process of reading and sorting all the student stories on contraceptive methods a pattern emerged. The authors identified three main stories - on hormonal contraception, digital contraception, and contraceptive responsibility. In the subsequent analysis several student stories were selected to display the pattern, and each of the stories was subjected to a close investigation of how the topic of contraception was approached. Although several other stories could have been told, we decided to follow a particular group of students throughout the analysis. The ten tentacles that emerged and unfolded in response to the student stories were further linked in the final and concluding analysis.

In the next paragraph the selected student stories on hormonal and digital contraception, and contraceptive responsibility are presented. The stories were audio-recorded; meanwhile, the students were working on their individual assignments. The assignment took several weeks to accomplish; therefore, the student stories run over several lessons and contain different groupings of students. They are, however, always concerning contraceptive methods. The first two stories are from the beginning of the students' work on norms.

\section{The call for a "natural" contraceptive method}

The classroom is alternately quiet and vibrant with chatter. The teacher is involved in the students' choice of topic, either supporting with verbal advice, distributing relevant literature, or giving a lecture on the hormonal regulation of sperm and ovarian follicle production to a smaller group of students. Two students, sitting next to each other, are searching the Internet for information related to their individual written assignments. As one of them explores norms about contraceptives, this soon becomes their talking point:

1. S1: Look! Women who have or have had breast cancer should not use hormonal [contraceptive] methods at all, because the cancer can be stimulated by oestrogen and progesterone. I don't even know what progesterone is!

2. S2: A major reason why I don't want to take [birth control] pills is because I have [had] so much trouble. I just got my period back [to what it was] naturally!

3. S1: Mmm.

4. S2: It's like this-I won't notice if I lose it [the period] ...

5. S1: No, no.

6. S2: ... it feels unsafe. I don't want [oral contraceptives] and my mother just [says]: Then you can use an etonogestrel contraceptive implant. And I'm just: No, I don't want it! It's still hormones! Gah! Woman!

The student story transforms the human body into a female hormonal contraceptive cyborg, with its first tentacle unfolding from scientific facts. The student story concerns scientific findings related to the use of hormonal contraceptives and, more specifically, the link between breast cancer and the use of hormone contraceptives (turn 1). According to a long-term British study, the use of hormonal contraceptives increases the risk of breast and cervical cancer. However, the risk seems to disappear approximately five years after discontinuing use (Iversen, Sivasubramaniam, Lee, Fielding and Hannaford, 2017). In the student's story the scientific facts captured the students' interest in hormones, for example 
progesterone (turn 1). The new interest was noticed by the teacher who later gave a detailed lecture on the hormones involved in contraception and reproduction for a smaller group of concerned students.

However, the scientific facts also caused feelings of uncertainty (turns 2, 4, 6), which led to the students opposing hormonal contraceptives as a birth control method (turns 2, 6). The plethora of hormonal contraceptives available to the students; e.g., the pill, etonogestrel contraceptive implant, vaginal ring, and IUS (intrauterine system), is further illustrated by the reported parent-child discussion on which method to choose (turn 6).

The second tentacle reveals the presence of educational policies. Since the 1970s, Swedish sexuality education has been aiming to inculcate sex positivism and sexual responsibility. The parent in question (turn 6) has most likely been educated with the same lust-oriented perspectives as her teenager-one may be sexually active but is also expected not to get involuntarily pregnant. Consequently, parental engagement with their children in discussions on contraceptive methods is no exceptional event - this parent is acting with politically correct, protective, and preventive intentions toward her sexually active teenager.

To sum up, the experience that hormonal contraceptives have several medical side effects both attracted interest and caused feelings of uncertainty among the students. The built-up student resistance and anxiety toward hormonal contraceptives formed the backdrop to the students' interest in a digital contraceptive method.

\section{Contraceptives as money-making businesses}

During the same lesson, the conversation has begun to run in a different direction as one of the students becomes interested in digital contraceptive methods. The student consults the teacher about a popular digital contraceptive, and in particular, its manufacturer's approach to advertisement:

7. S1: There is this digital contraceptive.

8. S2: They are developing a hormone-free contraceptive but I've heard that people got pregnant while using it so it feels a bit unsafe.

9. S3: Yes, that is the problem. It becomes a problem. But ...

10. T: Do you know what? If you really want to go deep into this I could, we have books that are, explain if you want to know how the digital contraceptive works and that. I could get [them].

11. S1: Can one write about the digital contraceptive as a business, or?

12. T: Yes, absolutely, it's probably very ...

13. S1: 'Cause it's [the digital contraceptive] everywhere, or it ...

14. T: Yes.

15. S1: There are a lot of people who...

16. T: Yes, and Influencer A makes money [joint laughter].

17. S1: Exactly, exactly!

18. T: Just let me know. I will, I can get that wagon [with the books] right away.

This student story transforms the human body into yet another female contraceptive cyborg, but this time it is digital. The third tentacle exposes market forces in the field of contraception. Over the last ten years, contraceptive smartphone applications have been marketed as a "hormone-free" and natural alternative. However, as the student story unfolds, the students call the credibility of digital contraceptives into question (turns 8,9 ). 
Both the rich publicity (turn 13) and the customers (turn 15), possibly the result of successful marketing plans, are commented on.

A fourth tentacle further explicates the role of social media in the marketing of digital contraceptive methods. One of Sweden's most successful influencers, Influencer A, coowns one of the digital contraceptive products, and it has often been promoted through her social media channels (turn 16). However, the credibility of Influencer A and her businesslike approach is brought into question by the collective laughter at the end of the conversation (turn 16).

In summary, the story concerns the student interest in contraceptive smartphone apps. The contraceptive method is called into question, mostly because of its promotion on social media.

\section{Problematizing the use of algorithms and thermometers}

The next student story is taken from a lesson a little later in the educational unit. The students have now decided on the norm to be explored and have had time to immerse themselves in their chosen subject areas. As stated in the previous student story, much of the rich publicity surrounding digital contraceptives comes from Swedish influencers, some of whom are health and fitness "gurus." This further reinforces the image of such contraceptives as "natural" alternatives:

19. S3: You follow Influencer B on Instagram?

20. S2: Come again?

21. S3: Influencer B.

22. S2: Yes.

23. S3: She got pregnant after using the digital application.

24. S2: Yeah.

25. S1: Damn. Has she sued them yet?

26. S3: Nah.

27. S2: I think that ...

28. S1: She may have made a mistake as well.

29. S2: Do you know who Influencer $\mathrm{C}$ is?

30. S3: No.

31. S2: She's also into health and exercise. She was going to test it too.

32. S3: [laughter]

33. S2: So, you hear then.

34. S1: Noooo! They [all] heard Influencer A.

The human body still transforms in the form of a digital contraceptive cyborg as this student story also concerns the use of popular digital contraceptives as well as influencers - this time from the field of health and fitness (turn 19, 31). The fifth tentacle, however, reveals the downside of contraceptive methods-unwanted pregnancies. The smartphone applications often work through an algorithm, computing the user's daily fertility status based on information about her basal body temperature (BBT) measurements during the menstruation cycle. The apps can therefore be used both for contraception and for pregnancy planning as the algorithm identifies with high precision the ovulation day and subsequent fertility days, given the correct input. The digital contraceptive method use 
of BBT is further based on medical research. In the late 1930s, the relationship between body temperature and time of ovulation captured medical attention (Davis 1946). The findings about basal body temperature were followed by the plotting of individual temperature graphs (Tompkins 1945). Already in the 1940s, researchers were emphasizing that basal body temperature needed to be accurately and precisely measured to be a reliable indicator. Alcohol consumption, interrupted sleep, exercise, and variation in the time of day measurements are taken may explain the reasons for the many unwanted pregnancies linked to the use of contemporary digital contraceptives. According to the student story, the pregnant Influencer B (turn 23) did not report her digital contraceptive failure to the appropriate agency, as suggested by the students (turn 25), and these contraceptives have been in the limelight elsewhere. In 2017, one of the contraceptive smartphone applications was reported to the Swedish Medical Products Agency by a group of midwives at an abortion clinic. The midwives linked many cases of unwanted pregnancies to the use of digital contraceptives, and this was well documented in the Swedish media.

To summarize, this story mainly concerns unwanted pregnancies due to the use of digital contraceptives. However, it also reveals the historical connotations of digital contraceptives, which are often promoted as a twenty-first-century discovery. The presence of health and fitness influencers further reinforces the idea of these contraceptives as "natural" alternatives.

\section{The algorithm of human ovulation}

This story is taken from a different lesson, where students again are discussing digital contraceptive methods. This time they are exploring the underlying mechanisms of reproduction in relation to digital contraceptive methods:

35. S4: [...] Is there not always, like, a risk or a chance or what can I say, to get pregnant throughout the, like, menstruation cycle?

36. S1: There's not! An egg can only be fertilised the day it leaves the ovary and a maximum of perhaps one day after. It's kind of a day and a half that it can be fertilised. So, if you have sex [sexual intercourse] five days before then, the sperm can survive, and you can get pregnant.

37. S2: They [the sperm] can survive.

38. S1: So it is roughly six days in an entire cycle that one can get pregnant. And that's what the digital contraceptive method builds on, and then they [the digital contraceptives] measure where you are in the cycle at all times.

39. S3: But what they believe is that then one [interrupts herself], or is it that you are just doing nothing during those days, or what?

40. S1: Either one must have some kind of protection or one has no sex at all.

41. S2: But why do they want that, what is their motivation for one to choose them [the digital contraceptive] over something else? Is it because it's more natural?

42. S1: Yes exactly, they talk a lot about it [the digital contraceptive] being natural and above all that there are no side effects. Because it was a couple who, all the time, were looking for the perfect contraceptive for her, but they found nothing.

43. S2: Yes, because birth control pills can have really serious consequences. For some, no birth control pills work.

44. S3: I have changed [birth control pills] four times. 
In this student story, the human body alternates between being a female hormonal and digital contraceptive cyborg. The first part of the student story explores the fertility period, i.e., when the egg and the sperm can fertilize one another (turns 35, 36, 38). As the story concerns the prediction of the fertility window, the main task of the digital contraceptive algorithm, the sixth tentacle is in the realm of scientific facts. Nevertheless, the students also use scientific facts to problematize the possibility of getting pregnant throughout the menstruation cycle due to the life span of the sperm (turns 37, 39, 40).

A seventh tentacle explicates stereotypical gendered and heteronormative assumptions as it describes how sperm fertilizes the egg (turn 36). With examples from the field of human reproduction, Emily Martin (1991) has questioned the production of stereotypical male and female attributes within biology research. The human egg is, for example, endowed with passive, "feminine" behavior-drifting along the fallopian tube to be penetrated by the active, streamlined, "masculine" sperm-delivering its genes to the egg. This is an image that persists despite recent research that has shown the egg coat plays an active and important role in the sperm-egg fertilization interaction (Martin, 1991). Malin Ah-King and Sören Nylin (2010) have done similar work but on animal mating behaviors. Consequently, the description of stereotypical and heterosexual patterns in biological and reproductive research affects the content of school textbooks (Ah-King, 2013).

The end of the student story touches upon the side effects of contraceptive methods (turns 42-44). An eighth tentacle therefore unfolds from the history of the contraceptive pill. In the mid-1900s research found that progesterone and estrogen suppress ovulation, which, in turn, initiated research on hormonal contraceptives (Dhont, 2010). The finding further coincided with concerns about global population growth. Yet, the pill's success story did not end as predicted by its developers and promoters-it never fulfilled the aim of controlling the world's growing population. Due to the pill's association with cardiovascular diseases in the late 1960s, its popularity within industrialized countries fell. Nevertheless, the contraceptive method also had advantages - it promoted female sexual independence and liberation from the continuous cycle of child birth (Marks, 2001).

To sum up, at the beginning of the story the students challenge the idea of a reliable algorithm as they pinpoint how the life span of sperm can affect the reliability of digital contraceptive methods. However, in the comparison between hormonal and digital contraceptives the side effects caused by exposure to hormones are also explicated. The student story further explicates stereotypical and heteronormative assumptions in biological and reproductive research, which in turn are reflected in school textbooks and classroom talk.

\section{Who is responsible for protection?}

This lesson is situated at the end of the educational episode. The student assignment was not only a way for the teacher to include the students' perspectives in education; it was also used for assessment. In this lesson the students are reading each other's work in preparation for the forthcoming oral and written examinations. The storytelling takes place in a larger student group as the students give feedback on each other's not-yet-finished texts: 
45. S2: You could discuss the issue, that for basically all contraceptives, or for the very large majority of them, the responsibility lies with the woman, in a way ...

[the other students mutter in agreement]

46. S3: I also think that's ...

47. S2: ... there is the condom and then vasectomy for men. I don't know if there is so much more.

48. S3: They were in the process of developing something, like some pills or some such, but I don't really think it's gone through [the entire development process] yet.

49. S2: What's the name? Eh, it's kind of a gel that you inject. Which is like a non-permanent vasectomy that will last for some years. But it may not, it's big in India but does not get research funding in the USA and such. Because, yes, it's not so big, the market doesn't want it.

50. S3: It's not like there are many who are pushing for the men to get that responsibility. They just put it on the women.

51. S1: So the question could be like this: so why is the responsibility to protect oneself on women? [writes on the computer]

52. S2: Mostly.

53. S1: And the uterus-carriers scream.

This student story turns the previous female contraceptive cyborgs into a male creature since it mainly problematizes the lack of successful male contraceptives, condoms excluded (turns 47-48). A ninth tentacle therefore awakens a concern for contraceptive responsibility $(45,50,51)$, a perspective which both sexuality education and school's general work on equality would benefit from. The students' questioning of both contraceptive responsibility and the research and development of contraceptive methods could be due to the norm-critical context framing the educational setting. The presence of norm criticism is also reflected in the student's use of the word uterus-carriers (turn 53), possibly an attempt to problematize the heterosexual base and male-female dichotomy permeating the discussion.

A tenth tentacle exposes the cultural and political influences on the success of a contraceptive method. The student story identified how the method developed in India, Reversible Inhibition of Sperm Under Guidance (RISUG; turn 49) has struggled to enter the US and European markets. The method works with an injection into the vas deferens and is effective for at least 10 years. It is also completely reversible with an injection of a rehabilitating chemical (Lohiya, Alam, Hussain, Khan and Ansari, 2014). So, the male contraceptive method is reproducing the history of the contraceptive pill, but in the reverse geographical direction-in the 1960s the contraceptive pill was rejected in India for political as well as cultural reasons. The pill's US origin, problems with the distribution, and economic factors contributed to hindering its spread to developing countries (Marks, 2001).

To summarize, this story shows how throughout history contraceptive responsibility has been placed upon women or uterus-carriers and how cultural and political factors affect the success of contraceptive methods. 


\section{Techno-biopolitics in Swedish sexuality education}

As this study links the cyborg image with the idea of tentacular thinking (Haraway, 1991, 2016) the contraceptive cyborgs are portrayed as tentacular creatures. However, the sprawling tentacular outgrowths originating in the student stories need to be linked.

The linking of the four gendered contraceptive cyborgs, originating from the student stories, shows how the techno-biopolitics of the Western world has mostly been concerned with the control of the female body. In the first part of the twentieth century, the approach to contraception was based on basal body temperature measurements and the plotting of individual temperature graphs. The temperature-regulated contraceptive method was then followed by a method which involved the oral intake of hormones, which was a shift to the artificial regulation of the female body. At the beginning of the twenty-first century, the contraceptive cyborg made yet another transformation-into digital. Digital contraceptive methods are, however, based on findings in the early 1900s, reproducing the history of the body basal temperature measurement approach and repackaging it as a twenty-first-century invention. Although the last student story offered us a male contraceptive cyborg, it also exposed how the Western world lacks a successful and lasting male contraceptive method. Consequently, contraceptive methods have since the 1950s been part of the apparatus of bodily production, used as means to maintain social and economic order through the control of the ovulation cycle (Haraway, 1991; Marks, 2001). The Swedish bio-technopolitics displayed in this study is, however, not only a result of scientific findings-it is also produced through education.

Sexuality education has, during the last fifty years, played a major role in fostering the attitudes of Swedish youth to sex and sexuality (Bredström, Bolander and Bengtsson, 2018). The sex-positive outset in education was coupled with an education on responsibility and prevention (Bolander, 2015; Bäckman, 2003; Sandström, 2001). Although the reproductive and contraceptive content is considered sufficient by adolescents (Public Health Agency of Sweden, 2017), the students of this study showed an interest in problematizing the side effects and gendered responsibility in relation to contraception. The stories are not just examples of ongoing discussions in the students' lives, and they might also contribute to the development of Swedish sexuality education, for example, by addressing the gendered responsibility in relation to contraceptive methods.

The contraceptive cyborgs tentacular intertwinings further showed that scientific facts were important for the students' to produce knowledge about human reproduction. The scientific facts also helped to navigate between the advantages and disadvantages of various contraceptive methods, for example how the methods worked and possible side effects. However, sexuality education is not just a matter of acquiring facts to distinguish between "right" and "wrong" information. It is also about conveying the understanding that scientific facts are part of an historical, political, cultural, and market-oriented knowledge web of interests-a techno-biopolitical knowledge web of interests.

The tentacle intertwining's also displayed the specific cultural context framing this study, for example the Swedish norm-critical pedagogy, which also is part of the technobiopolitics influencing the production of sexuality education. In this study, the norm-critical stance was a choice made by the teacher to follow the current regulatory guidelines for sexuality education (Swedish National Agency for Education, 2013a,b, 2014). The teacher also let the students work on the norms they were interested in to include them in the production of sexuality education (Allen, 2005). However, although the process of identifying and exploring sexuality norms aimed at challenging them, the students were 
also reproducing the same norms, in particular, norms about the male-female dichotomy, heterosexuality, and norms about duality. Although a reproduction of norms in classroom settings was not the focus of our study, the student stories show that this is a matter which needs further research and investigation.

\section{Conclusions}

The theoretical and analytical approach of this study aimed to offer an in situ understanding of student knowledge production in education on contraceptive methods. The student stories highlight the relationship between gender and contraception. Therefore, who is responsible for protective actions, and stereotypical gendered and heteronormative assumptions in textbooks and talks need to be challenged within sexuality education.

We further showed that natural science, historical, cultural, political, and market-oriented interests affected students' notions of contraception. Consequently, contraception should not only be taught as a matter of scientific facts but also from its broader intertwining's.

Acknowledgements We thank the students and the teacher who participated in our research project.

Funding Open access funding provided by Stockholm University.

Open Access This article is licensed under a Creative Commons Attribution 4.0 International License, which permits use, sharing, adaptation, distribution and reproduction in any medium or format, as long as you give appropriate credit to the original author(s) and the source, provide a link to the Creative Commons licence, and indicate if changes were made. The images or other third party material in this article are included in the article's Creative Commons licence, unless indicated otherwise in a credit line to the material. If material is not included in the article's Creative Commons licence and your intended use is not permitted by statutory regulation or exceeds the permitted use, you will need to obtain permission directly from the copyright holder. To view a copy of this licence, visit http://creativecommons.org/licenses/by/4.0/.

\section{References}

Ah-King, M. (2013). Queering animal sexual behavior in biology textbooks. Confero Essays on Education Philosophy and Politics, 1(2), 46-89. https://doi.org/10.3384/confero.2001-4562.13v1i21d

Ah-King, M., \& Nylin, S. (2010). Sex in an evolutionary perspective: Just another reaction norm. Evolutionary Biology, 37(4), 234-246. https://doi.org/10.1007/s11692-010-9101-8

Allen, L. (2005). 'Say everything': Exploring young people's suggestions for improving sexuality education. Sex Education, 5(4), 389-404. https://doi.org/10.1080/14681810500278493

Allen, L., \& Rasmussen, M. L. (2017). Introduction to the palgrave handbook of sexuality education. In L. Allen \& M. L. Rasmussen (Eds.), The palgrave handbook of sexuality education (pp. 1-19). Palgrave Macmillan UK.

Årman, H. (2020). Affects of verbal hygiene: The impact of language activism at a Swedish high school. Language Policy, 20, 151-171. https://doi.org/10.1007/s10993-020-09543-3

Bolander, E. (2015). The condom works in all situations? Paradoxical messages in mainstream sex education in Sweden. Sex Education, 5(3), 289-302. https://doi.org/10.1080/14681811.2015.1010075

Bredström, A., Bolander, E., \& Bengtsson, J. (2018). Norm-critical sex education in Sweden. Tensions within a progressive approach. In S. Lamb \& J. Gilbert (Eds.), The Cambridge handbook of sexual development: childhood and adolescence (pp. 537-558). Cambridge: Cambridge University Press.

Bäckman, M. (2003). Kön och känsla: Samlevnadsundervisning och ungdomars tankar om sexualitet. [Sex and emotion. Education in sexual matters and young people's thoughts about sexuality.]. Makadam förlag. 
Dahlöf, A-M. (director) (2011). Sex on the map. The Swedish Educational Broadcasting Company, The Swedish Association for Sexual Education and Eksjö Animation studio.

Davies, B. (2014). Reading anger in early childhood intra-actions: A diffractive analysis. Qualitative Inquiry, 20(6), 734-741. https://doi.org/10.1177/1077800414530256

Davis, M. E. (1946). The clinical use of oral basal temperatures. The Journal of the American Medical Association. https://doi.org/10.1001/jama.1946.02870140021007

Dhont, M. (2010). History of oral contraception. The European Journal of Contraception and Reproductive Health Care, 15(2), 12-18. https://doi.org/10.3109/13625187.2010.513071

EU 2016/679. (2016). General Data Protection Regulation. Article 9, Processing of special categories of personal data.

Foucault, M. (1980). Sexualitetens historia, 1. Viljan att veta. [The history of sexuality: 1. The will to know.]. Gidlunds förlag.

Foucault, M. (2008). Samhället måste försvaras: Collège de France 1975-1976. [The society must be defended. Lectures at the college de france, 1975-76.]. TankeKraft förlag.

Foucault, M. (2010). Säkerhet, territorium, befolkning: Collège de France 1977-1978. [Security, territory, population. Lectures at the college de france, 1977-78.] TankeKraft förlag.

Franzke, A. S, Bechmann, A., Zimmer, M., Ess, C. and the Association of Internet Researchers (2020). Internet research: ethical guidelines 3.0. https://aoir.org/reports/ethics3.pdf

Haraway, D. (1991). Simians, cyborgs, and women: the Reinvention of nature. Free Association Books.

Haraway, D. (2016). Staying with the trouble: Making kin in the Chthulucene. Duke University Press.

Hultén, M. (2008). Naturens kanon: formering och förändring av innehållet i folkskolans och grundskolans naturvetenskap 1842-2007. [Nature's canon: the formation and change of the science curriculum in Swedish compulsory school 1842-2007.]. Pedagogiska institutionen, Stockholms universitet.

Iversen, L., Sivasubramaniam, S., Lee, A. J., Fielding, S., \& Hannaford, P. C. (2017). Lifetime cancer risk and combined oral contraceptives: The royal college of general practitioners' oral contraception study. American Journal of Obstetrics and Gynecology, 216(6), 580.e1-580.e9. https://doi.org/10.1016/j. ajog.2017.02.002

Ketting, E., \& Ivanova, O. (2018). Sexuality education in Europe and Central Asia. State of the art and recent developments. An overview of 25 countries. The German Federal Centre for Health Education, $\mathrm{BZgA}$ and the International Planned Parenthood Federation European Network (IPPF EN).

Kumashiro, K. (2000). Toward a theory of anti-oppressive education. Review of Educational Research, 70(1), 25-53. https://doi.org/10.3102/00346543070001025

Langmann, E., \& Månsson, N. (2016). Att vända blicken mot sig själv: en problematisering av den normkritiska pedagogiken. [Turning the gaze towards oneself: a problematization of norm-critical pedagogy, our translation.]. Pedagogisk forskning i Sverige, 21(1-2), 79-100.

Lemke, T. (2011). Biopolitics: An advanced introduction. New York University Press.

Lohiya, N. K., Alam, I., Hussain, M., Khan, S. R., \& Ansari, A. S. (2014). RISUG: An intravasal injectable male contraceptive. The Indian Journal of Medical Research, 140(1), 63-72.

Marks, L. V. (2001). Sexual chemistry: A history of the contraceptive pill. Yale University Press.

Martin, E. (1991). The egg and the sperm: How science has constructed a romance based on stereotypical male-female roles. Signs: Journal of Women in Culture and Society, 16(3), 485-501. https://doi.org/10. $1086 / 494680$

Mazzei, L. A. (2014). Beyond an easy sense: A diffractive analysis. Qualitative Inquiry, 20(6), 742-746. https://doi.org/10.1177/1077800414530257

Ojankangas, M. (2017). Biopolitics in the political thought of classical Greece. In S. Prozorov \& S. Rentea (Eds.), The Routledge handbook of biopolitics (pp. 23-35). Routledge.

Ollis, D. (2016). 'I felt like I was watching porn': The reality of preparing pre-service teachers to teach about sexual pleasure. Sex Education, 16(3), 308-323. https://doi.org/10.1080/14681811.2015.10753 82

Public Health Agency of Sweden. (2017). Sexuality and Health among Young People in Sweden UngKAB15 - a Survey on Knowledge, Attitudes and Behaviour among Young People 16-29 Years Old.

Ringrose, J., Whitehead, S., Regehr, K., \& Jenkinson, A. (2019). Play-Doh vulvas and felt tip dick pics: Disrupting phallocentric matter(s) in sex education. Reconceptualizing Educational Research Methodology, 10(2-3), 259-291. https://doi.org/10.7577/rerm.3679

Sandström, B. (2001). Den välplanerade sexualiteten: frihet och kontroll i 1970-talets svenska sexualpolitik. [The wellplanned sexuality: freedom and control in the Swedish sexual politics of the 1970s.]. HLS förlag.

Swedish National Agency for Education. (2012). Syllabus Science studies, upper secondary school.

Swedish National Agency for Education. (2013a). Sex- och samlevnadsundervisning i grundskolans senare år: jämställdhet, sexualitet och relationer i ämnesundervisningen. Årskurserna 7-9. [Sex and relations 
in lower secondary school: gender equality, sexuality and relationships for subject specific education. Year 7-9, our translation].

Swedish National Agency for Education. (2013b). Sex- och samlevnadsundervisning i gymnasieskolan: sexualitet, relationer och jämställdhet $i$ de gymnasiegemensamma ämnena. [Sex and relations in upper secondary school: sexuality, relationships and gender equality in upper secondary school subjects, our translation].

Swedish National Agency for Education. (2014). Sex- och samlevnadsundervisning i grundskolans tidigare år: jämställdhet, sexualitet och relationer i ämnesundervisningen. Årskurserna 1-6. [Sex and relations in primary school: gender equality, sexuality and relationships for subject specific education. Year 1-6, our translation].

Swedish Schools Inspectorate. (2018). Sex- och samlevnadsundervisning. Tematisk kvalitetsgranskning. [Sex education. Thematic quality review, our translation].

Taguchi, H. L. (2012). A diffractive and Deleuzian approach to analysing interview data. Feminist Theory, 13(3), 265-281. https://doi.org/10.1177/1464700112456001

Tompkins, P. (1945). The timing of ovulation by basal temperature graphs. The Medical Clinics of North America, 29, 1425-1434. https://doi.org/10.1016/s0025-7125(16)36014-x

Publisher's Note Springer Nature remains neutral with regard to jurisdictional claims in published maps and institutional affiliations.

Sara Planting-Bergloo is a PhD student in science education at the Department of Mathematics and Science Education, Stockholm University. With a background as an upper secondary Chemistry and Biology teacher her research interest is in science education with a focus on sexuality education.

A. A. Orlander is associate professor in science education and Director of Studies at the Department of Mathematics and Science Education. With a background as a teacher, teacher educator, educational consultant, she has become in contact with practice-related issues in the field. Her interest is in science education with a focus on gender.

B. Jakobson is associate professor in science education at the Department of Mathematics and Science Education, Stockholm University. Her research interest is in elementary school students' meaning-making in science, especially focusing on art activities and aesthetic experience. In addition, she has a research interest in second language learners' meaning-making in science. 